\title{
Why We Need Erga Omnes Character for Obligations to Combat Impunity for International Crimes?
}

\begin{abstract}
Diajeng Wulan Christianti*
DOI: https://doi.org/10.22304/pjih.v4n2.a8

Abstract

International law has recognized certain crimes as international crimes or the most serious crimes. However, it is arguable whether the prohibitions of international crimes that have reached the status of jus cogens carry with it the duty to combat impunity that has same legal consequences as jus cogens namely non-derogable and universal. In Barcelona Traction Case Judgment, ICJ purported the concept of erga omnes obligations that are obligations toward international community as whole and enables all states to establish their rights of protection in the case of the breach of obligations. Although the Court exemplified four examples of erga omnes obligations that generally reflect the prohibitions of certain international crimes, the relationship between jus cogens and erga omnes remains unclear. This article thus examines this relationship since it conceives as necessary element to determine the superior status of erga omnes obligations to combat impunity in international law. This status is significant for enforcing international criminal law and promoting global justice. The article aims to determine theoretically the added values of having erga omnes character.
\end{abstract}

Keywords: erga omnes, human rights, impunity, international crimes, jus cogens.

\section{Mengapa Kita Membutuhkan Karakter Erga Omnes sebagai Kewajiban dalam Memerangi Impunitas untuk Kejahatan Internasional?}

\begin{abstract}
Abstrak
Hukum internasional telah mengakui kejahatan tertentu sebagai kejahatan internasional atau kejahatan paling serius. Namun, terdapat perdebatan terkait larangan kejahatan internasional yang telah mencapai status jus cogens membawa serta tugas untuk memerangi impunitas yang memiliki konsekuensi hukum yang sama dengan jus cogens yang tidak dapat dikurangi dan universal. Mahkamah Internasional melalui Putusan Kasus Barcelona Traction mengakui konsep kewajiban erga omnes yang merupakan kewajiban terhadap masyarakat internasional secara keseluruhan dan memungkinkan semua negara untuk menetapkan hak perlindungan mereka dalam kasus pelanggaran kewajiban. Meskipun Mahkamah menyertakan empat contoh kewajiban erga omnes yang umumnya mencerminkan larangan kejahatan internasional tertentu, hubungan antara jus cogens dan erga omnes tetap tidak jelas. Dengan demikian, artikel ini akan menguji keterkaitan tersebut karena mengandung unsur yang diperlukan untuk menentukan status superior kewajiban erga omnes untuk memerangi impunitas dalam hukum internasional. Status ini penting untuk menegakkan hukum pidana internasional dan mempromosikan keadilan global.

PADJADJARAN Jurnal IImu Hukum Volume 4 Nomor 2 Tahun 2017 [ISSN 2460-1543] [e-ISSN 2442-9325]

* Lecturer at Universitas Padjadjaran, Jl. Dipati Ukur No. 35, wulan.christianti@unpad.co.id , S.H. (Universitas Padjadjaran), LL.M. (University of Geneva).
\end{abstract}


Selain itu, artikel ini pun bertujuan untuk mengetahui secara teoritis nilai tambah karakter ergaomnes.

Kata kunci: erga omnes, hak asasi manusia, impunitas, kejahatan internasional, jus cogens.

\section{A. Introduction}

Serious violations of human rights, which are also recognized as international crimes, shall be universally opposable since they shock the conscience of mankind and result in great losses to humanity. The first consequence arising from outlawing of such gravest crimes, as stipulated in International Court of Justice (ICJ) Advisory Opinion in 1951 Genocide Convention, is that 'the underlying principle is binding on states even without any conventional obligation'. ' This is due to the fact that state does not create human rights but just confirms their existence. Human rights derive from the very concept of a person hence it exists independently from the will of a state. $^{2}$

Applicability of universal criminal jurisdiction and proliferation of international criminal tribunals appeared as the reasons of international community to collectively respond and repress international crimes. These also attest to the existence of international community which are strong enough to prompt to punish offenders even if it has to take risks of undermining some of its foundations namely sovereignty or immunity. Those phenomena lead to the emergence of International Criminal Law (ICL) which is often presented as the road to international criminal justice. ${ }^{3}$ Preventing impunity therefore is a goal of international criminal justice since it is essentially a means of deterrence and part of the overall objective to prevent atrocities. Unfortunately, international crimes still widely occur and most of states are reluctant to prosecute or extradite the suspect. This is due to the fact that existing sources of international (criminal) law do not provide sufficient basis with regard to the legal consequences of recognizing crimes as international crimes. Even if they provide such consequences, it is unclear whether those which do not derive from conventional obligations impose legally binding obligations on all states.

In the 1970 Judgment of Barcelona Traction Case, ICJ for the first time purported the concept of erga omnes as obligation that is owed toward international

1 International Court of Justice (ICJ), "Advisory Opinion on Reservation to the Convention on the Prevention and Punishment Crime of Genocide", ICJ Report May 28 $8^{\text {th }}, 1951$, p. 23.

2 Dissenting Opinion of Judge Tanaka in ICJ Judgment on South West Africa Case for finding that the applicant states (Ethiopia and Liberia) lacked of standing. See Maurizio Ragazzi, "International Obligations Erga Omnes: Their Moral Foundation and Criteria of Identification in the Light of Two Japanese" in Guy S Goodwin-Gill and Stefan Talmon, The Reality of International Law, Oxford: Oxford University Press, 1999, pp. 464-465.

3 At a fundamental level, international criminal justice describes the response of international community to mass atrocity. See Gideon Boas, "What is International Criminal Justice", in Gideon Boas, William Schabas, Michael P Scharf (eds), International Criminal Justice: Legitimacy and Coherence, United Kingdom: Edward Elgar Publishing Limited, 2012, p. 1. 
community as a whole and distinguished it from other obligations that are reciprocal in character. ${ }^{4}$ According to the Judgment, erga omnes conception enables all states to put forward claim against responsible state which breaches such obligations. ${ }^{5}$ ICJ listed four examples of obligations erga omnes namely outlawing of acts of aggression and genocide and protection from slavery and racial discrimination. ${ }^{6}$ By the same token, outlawing of international crimes has been widely accepted as jus cogens. ${ }^{7}$ Yet, positive ICL never fully clarifies as for the effect of characterizing prohibition of international crimes as jus cogens and the relationship between jus cogens and erga omnes. ${ }^{8}$

Some lawyers argue that erga omnes obligations place higher status than other international obligations. ${ }^{9}$ Liderfalk uses this proposition as the Theory on the Superior Status of Erga Omnes Obligations. ${ }^{10}$ On that account, the present writer preliminarily observes the significant character of erga omnes obligations compares to other customary international law obligations by identifying common elements of four examples obligations that ICJ considered as erga omnes obligations. This will also include the discussion concerning the relationship between erga omnes obligations and jus cogens. Assuming that due to their significant character, erga omnes obligations are hierarchically superior than other international obligations, this conclusion will be used as a legal basis for examining the central question of this paper namely why we need erga omnes character for obligations to combat impunity for international crimes.

4 C. Annacker, "The Legal Regime of Erga Omnes Obligations in International Law", 46 Austrian Journal of Public and International Law, 1994, p. 136.

5 Barcelona Traction Case para. 33; See Andre de Hoogh, Obligation Erga Omnes and International Crimes, The Netherlands: Kluwer Law International, 1996, pp. 54-55.

6 Barcelona Traction Case para. 34 states that: “...outlawing of acts of aggression, and of genocide, as also from the principles and rules concerning the basic rights of human person, including protection from slavery and racial discrimination."

7 International Law Commission (ILC) Reports of the Study Group on Fragmentation of International Law, "Difficulties arising from the diversification and expansion of international Law, A/CN.4/L.682", 13 April 2006, para. 374. It also mentions in Commentary Article 40 of ILC Draft Articles on Responsibility of States for Internationally Wrongful Act (ARSIWA) para. 4-6 Yearbook of ILC, 2001, Vol. II, Part Two, pp. 112-113.

8 Bassiouni remarked "the exact contours of each of these concepts are controversial, and therefore, any statement about the relationship between them is likely to be controversial as well", M. Cherif Bassiouni and Edward M. Wise, Aut Dedere Aut Judicare: The Duty to Extradite or Prosecute in International Law, The Netherlands: Kluwer Academic Publishers, 1995, p. 51.

9 Andre de Hoogh refers to international legal obligations erga omnes as "obligations of a higher normative value". Andre de Hoogh, Op.cit, p. 55. Erika de Wet expresses those obligations as "constitute a second layer of the international value system, below that of peremptory norms", in Erika de Wet, "The Emerging International Constitutional Order: The Implications of Hierarchy in International Law for the Coherence and Legitimacy of International Decision Making", Potchefstroom Electronic Law Journal 2, 2007, pp. 1-27. Malcolm Shaw states that erga omnes obligatons are "of a different or higher status that others", in Malcolm Shaw, International Law, $6^{\text {th }}$ Edition, New York: Cambridge University Press, 2008, p. 124.

10 Ulf Linderfalk, "International Legal Hierarchy Revisited-The Status of Obligations Erga Omnes", 80 Nordic J.International L.1, 24, 2011, pp. 1-23. 
The aim of this paper is to provide theoretical foundation of erga omnes obligations for a State to establish its right to demand the performance of breached obligations to combat impunity for international crimes. Consequently, this will affect the enforcement of ICL and hence achieve global justice.

\section{B. The Superior Status of Erga Omnes Obligations}

This article begins with identifying the scope and criteria of erga omnes and its relationship with jus cogens since jus cogens are conceived as concept triggered the institution of erga omnes obligations. It will be concluded by determining whether or not erga omnes obligations are hierarchically superior than other customary international obligations.

\section{Identifying Erga Omnes Obligations: The Scope and Criteria}

Erga omnes is latin expression which means 'towards all or against all'. ${ }^{11}$ The Court made essential distinction between obligations towards the international community as whole (erga omnes) and those arising towards other individual states (in this case is diplomatic protection). However, the Court has created some confusion by stating that these are obligations which are 'the concern of all States'. This is because all obligations derived from customary international law are also 'the concern of all States' that is, all States have to respect their observance. ${ }^{12}$ The essential idea of the innovation of erga omnes concept in the Barcelona Traction dictum is that in case of breach of such obligation the "corresponding rights of protection" are in possession of each and every state..$^{13}$ This can be seen when the Court held that "all States can be held to have a legal interest in their protection". In other words, erga omnes is a consequence of a breach of fundamental importance rights. ${ }^{14}$ This identifies that ICJ focuses not on the primary rules but the secondary rules. $^{15}$

If erga omnes is connected to the realm of secondary rules in international law, what is then the criteria of primary rules that may impose erga omnes obligations on state? In other words, how an international obligation may be regarded as being erga omnes. In paragraph 34, ICJ provided non-exhaustive list of examples of

11 P. G. W. Glare, Oxford Latin Dictionary, Oxford, 1982, 1248-9 (omnis).

12 Fourth Report, 21, Yearbook of ILC 1983 in Andre Hoogh, Op.cit., p. 26 and 53. See also Antonio Cassese and Marina Spinedi (eds), International Crimes of Sates: A Critical Analysis of the ILC's Draft Article 19 on State Responsibility, Berlin: Walter de Gruyter \& Co, 1989, p. 237.

13 In paragraph 34 of the Barcelona Traction Case dictum, the Court stated that "...Some of the corresponding rights of protection have entered into the body of general international law...".

14 See Andre Hoogh, Op.cit., p. 53. Theodor Meron also states that "Moreover, being erga omnes is a consequence, not the cause, of a right's fundamental character" in Theodor Meron, "On A Hierarchy of International Human Rights", 80 American Journal of International Law 1, January 1986, p. 9.

15 Roberto Ago, in his second report of State Responsibility, Yearbook of ILC 20 April 1970, p.179. 
obligations that have erga omnes characterizations namely prohibiting aggression, genocide, slavery and racial discrimination. ${ }^{16}$ This has raised question of whether or not one can extract the criteria of erga omnes from those four obligations listed by the Court. According to Professor de Hoogh, there is no criterion of erga omnes that can be extracted due to the differing character of the examples given by the Court. ${ }^{17}$ Yet, Ragazzi comes with at least five common elements of the four examples of obligations ${ }^{18}$ which he conceives that those elements will provide useful framework of analysis of new candidates of erga omnes obligations particularly those candidates that are in conflict with the four examples or incompatible with the underlying values. $^{19}$

The five common elements provided by Ragazzi are also known as 'Material Approach' that reflect the superior status of erga omnes due to its function to protect and promote important values and interest. ${ }^{20}$ There is discussion among scholars as to what extent one value is more important than others. ${ }^{21}$ For the purpose of brevity, taking into consideration that the candidates that will be discussed in this article belong to international crimes, the four of examples of erga omnes obligations given by ICJ show that this concept has heavily been approached from the perspective of particular areas of the law namely international human rights law and international criminal law. It can be concluded that other candidates of erga omnes obligations pertaining to international crimes will continue to be privileged domain for the development of erga omnes obligations. ${ }^{22}$ It is thus relatively easy to justify further enquiry into area of international criminal law.

16 Paragraph 34 of Barcelona Traction Case

17 Andre de Hoogh, Op.cit., p. 54.

18 This opinion is to criticize de Hoogh propositions. The five common elements of all four examples are (1) narrowly defined obligations; (2) negative obligations (or prohibitions); (3) obligations or duties in the strict sense (i.e what ought or ought not to do) to the exclusion of other fundamental legal conception; (4) deriving from rules of general international law belonging to jus cogens and codified by international treaties to which a large number of states have become parties; and (5) obligations instrumental to the main political objectives of the present time, namely, the preservation of peace and the promotion of fundamental human rights which in turn reflect basic goods (or moral values). See Maurizio Ragazzi, The Concept of International Obligations Erga Omnes, Oxford: Oxford Monograph in International Law, Clarendon Press, 1997, pp. 132-134.

19 To name an example is the Nuclear Test Case. The prohibition of atmospheric testing was opposable to France, New Zealand referred to the underlying values of the obligations erga omnes identified by ICJ in Barcelona Traction Case.

20 According to Christian J Tams, "Material Approach" is one of the approaches to distinguish erga omnes obligations from other customary obligations because of the importance of the substance of those norms. By the same token, Ragazzi enumerates five common elements of erga omnes obligations listed by ICJ particularly the fact that the four examples deriving from jus cogens and they are instrumental to the main preservation of peace and promotion of fundamental human rights. See Ragazzi, Op.cit., p. 134. See also Christian J Tams, Enforcing Obligations Erga Omnes in International Law, United Kingdom: Cambridge University Press, 2005, p. 129.

21 See Ulf Linderfalk, Op.cit., p. 8.

22 The further discussion concerning erga omnes character for international crimes will be seen in the next section. 
Furthermore, one can also refer to jus cogens to define the important value as international law places it at the level of the fundamental principles in international system.

The second approach to distinguish erga omnes from other customary obligations is they are the non-bilateralizable or non-reciprocal in nature which also known as 'Structural Approach'. ${ }^{23}$ These obligations have to be performed in relation to all states and they consequently create legal interest of all states in its observance. ${ }^{24}$ In the words of Christian J Tams, the nature of these obligations transcend the reciprocal (or bilateral) relations between pairs of States. ${ }^{25}$ By the same token, Bruno Simma stated that jus cogens and erga omnes rules represent the antithesis of bilateralism. ${ }^{26}$ Although bilateral legal relationship can be multiplied so that similar relationships exist between all States and thus the rule becomes general in application, this does not apply to erga omnes since the violation of such rules does not automatically establish rights of all States to claim.

In conclusion, referring to Barcelona Traction Case dictum, there are two significant characteristics features of obligation erga omnes. First, obligations acquire erga omnes status if they are 'non-reciprocal or non-bilateralizable' since all States have legal interest in their observance. ${ }^{27}$ Second, the primary rules of this norms are important value, in the sense that they protect common/collective interest that every State is deemed to have legal interest in their protection. Of these two characteristics, the former provides legal standing of all States to demand other states for non-performance of the obligations. Meanwhile, the latter pertains to the common elements of four examples of obligations that Court has listed in the dictum.

\section{The Superior Status of Erga Omnes Obligations: The Relationship between Jus Cogens and Erga Omnes and Its Legal Consequences}

The emergence of jus cogens determined that there are rules consist in the fact that they do not exist to satisfy the needs of individual state but the higher interest of the whole international community. ${ }^{28}$ Subsequently, the breach of higher interest considers as the breach toward international community as a whole that renders all state to claim against the responsible state (erga omnes). Article 53 of Vienna

23 Christian J Tams, Op.cit., p. 130.

24 Paragraph 35 of Barcelona Traction Judgment 1970.

25 Christian J Tams, Loc.cit.

26 See Bruno Simma, "Bilateralism and Community Interest in the Law of State Responsibility", in Yoram Dinstein (ed), International Law at a Time of Perplexity: Essay in Honour of Shabtai Rosenne, Dordrecht: Nijhoff, 1989, p. 822.

27 Christian J Tams, Op.cit., p. 129.

28 The comprehensive explanation concerning the historical, development and criteria of jus cogens can be seen in L. Hannikanen, Peremptory Norms (Jus Cogens) in International Law: Historical, Development, Criteria, Present Status, Helsinki: Lakimiesliiton Kustanus Finish Lawyers' Publishing Company, 1988, p. 30. 
Convention on the Law of Treaty (VCLT) seems to determine that positivist theory is the theoretical foundation of this norm and it continues to dominate the development of international law. ${ }^{29}$ Positivist theory argues that in order to attain the status of jus cogens, customary international must be verified by the state consent. This is the reason why the positivist claim that authority of jus cogens norms can be found in CIL. ${ }^{30}$ However, the positivist finds difficulties in explaining why jus cogens would bind third parties or persistent objector. ${ }^{31}$

Positivist is also uncomfortable when it has to deal with interaction between treaty, CIL, and jus cogens. ${ }^{32}$ In the case that treaty contracts out of certain CIL rules, state parties to the treaty are not bound by CIL rules. ${ }^{33}$ This does not apply for jus cogens since if emerging or existing treaty conflicts with existing or emerging norms of jus cogens the treaty is void. ${ }^{34}$ This is not the case with jus cogens with its nonderogation character. It can neither be displaced by treaty nor be removed as a norm of general international law by way of treaty but only by the emergence norm with the same status. ${ }^{35}$

Unlike the other sources of international law, jus cogens is 'above' or 'prior' to the will of state. ${ }^{36}$ Hence, the authority of jus cogens norms has to be prior or above which would transform the willingness of all state to abide the norms and not through threat or coercion. Referring heavily to VCLT as a source of jus cogens and thus conclude that the authority of this norm is state consent is problematic. This is because VCLT, as treaty, remains limited in scope and applicability. It applies only to treaty and binds only to state parties of the treaty. Although VCLT has reached the status of $\mathrm{CIL}$, it still cannot apply toward the persistent objectors.

29 Article 53 of Vienna Convention of the Law of Treaties (VCLT) shows as a whole points towards the consensusbased positivist's approach. See, D Shelton, "Normative Hierarchy in International Law", 100 American Journal of International Law, 291, 2006, p. 300.

30 See. M. Byers, Op.cit., p. 227.

31 D. Dubois, "The Authority of Peremptory Norms in International Law: Sate Consent or Natural Law?", Nordic JIL 78, 2009, p. 137.

32 Michael P. Scharf, Customary International Law in Times of Fundamental Change: Recognizing Grotian Moments, Cambridge: Cambridge University Press, 2013, p. 41.

33 D. Dubois, Op.cit., p. 138. Dubois refers to J. H. Currie (et.al), International Law: Doctrine, Practice and Theory, Toronto: Irwin Law, 2007, p. 141.

34 In separate provision, Article 64, the existing treaty is void if it conflicts with a rule of new peremptory norms: "If a new peremptory norm of general international law emerges, any existing treaty which is in conflict with that norm becomes void and terminates." In both instances, jus cogens trumps existing or new treaty and rendering it void in its entirety.

35 D. Dubois, Op.cit., p. 141.

36 Lauterpacht analysis in his 1993 separate opinion on a request for provisional measures in the Case Concerning Application of the Convention on the Prevention and Punishment of the Crime of Genocide that applied the concept of jus cogens to the question of the legality of the arms embargo which had been imposed on BosniaHerzegovina by the United Nations Security Council (UNSC). He stated that "the concept of jus cogens operates as a concept superior to both customary international law and treaty...". This analysis showed that jus cogens may also override even the most authoritative form of executive action known to international society should that authority be exercised in violation of that rule. See Michael Byers, "Conceptualizing the Relationship 
As the ambit of peremptory norms is much wider that what is set out in VCLT, Lauterpacht rightly articulated that the higher norms must be general principles of international morality and public policy. ${ }^{37}$ Simma also conceded that the conception of jus cogens will remain incomplete as it is not based on a philosophy of values like natural law. ${ }^{38}$ The universal binding character as well as no derogation thus place jus cogens at the top of the hierarchy of international law. In conclusion, having jus cogens character as primary rule and consequently raise the obligations erga omnes as secondary rules gives added legal value namely the norm is above the will of a state and hence universally binding toward all state without consent even toward a state that persistently objects such norm.

Some scholars argue that unlike jus cogens, erga omnes rules do not preclude the possibility of persistent objector nor possibility that erga omnes rules apply limited only toward States which party to the relevant treaty (erga omnes partes). ${ }^{39}$ Obligations derive from Human Rights Conventions are one of the examples of erga omnes partes which the word 'omnes' in this respect is limited only towards the state parties to the Conventions. ${ }^{40}$

As already discussed in the preceding paragraphs, the definition of erga omnes as obligations that 'concern of all states' is a misnomer. On this account, it is thus necessary to see the intention of the ICJ when it articulated the concept of erga omnes in Barcelona Traction Case dictum as its innovation. The Court intended to emphasize on the consequence of violations by establishing the rights of protections of all states, rather than a cause. This is explained why erga omnes in this dictum is different from erga omnes partes, since the obligations that 'concern of all states' does not automatically entail all states to put forward claim for their observance.

Although ICJ never expressly pronounces the relationship between jus cogens and erga omnes, the four examples of obligation erga omnes referred to by the Court have been named as prime examples of jus cogens during the Vienna Conference. ${ }^{41}$ Erga omnes listed by ICJ in Barcelona Traction are exceptionless moral

between Jus cogens and Erga Omnes Rule", Nordic Journal International Law 66: 211-239, Kluwer Law International, Netherlands, 1997, p. 217.

37 Natural classical writers recognized 'principles' of jus natural necessarium from which all states are obliged to observe as the starting idea of jus cogens norms. See Alfred Verdross, "Jus Dispositivum and Jus Cogens In International Law", The American Journal of International Law, Vol.60, 1966, p. 56. See also Rafael Nieto-Navia, "International Peremptory Norms (Jus cogens) and International Humanitarian Law" in Lal Chand Vohrah (et.al) (eds), International Humanitarian Series: Man's Inhumanity to Man: Essays on International Law in Honour of Antonio Cassese, The Netherlands: Kluwer International Law, 2003, p. 599.

38 Bruno Simma, "The Contribution of Alfred Verdross to the Theory of Law", European Journal of International Law 6, 1995, p. 53.

39 See Michael Byers, Op.cit., p. 233, See also Ulf Linderfalk, Op.cit, p. 12.

40 For the latest development concerning erga omnes partes, see Questions relating to the Obligation to Prosecute or Extradite (Belgium v Senegal) 2012, ICJ Rep, (Habré decision), paras. 42 and 69.

41 Andre de Hoogh, Op.cit., p. 55. 
norms therefore it is unnecessary to further challenge their binding force. ${ }^{42}$ Furthermore, in respect with international crimes, Bassiouni states that "jus cogens refers to the status that certain international crimes reach and erga omnes pertains to the legal implications arising out of certain crime's characterization as jus cogens". ${ }^{43}$ This proposition also answers the criticism of the opponent of the Theory of Superior Status of Erga Omnes who mentioned that the two characteristics of erga omnes namely 'non-bilateral' and 'important values' are rather creating confusing and disorganization of international law. ${ }^{44}$ This is because they still perceive that norms expressing erga omnes is different norm that is inferior than jus cogens (but superior to other non-peremptory norms).$^{45}$ It will make the application of jus cogens problematic. Therefore, likewise jus cogens, erga omnes concept applies to all states regardless whether the state has continuously protested against it.

\section{Outlawing of International Crimes as Jus Cogens}

The following section will examine the 'truly international nature' of international crimes which invoke the collective will of international community to condemn and internationally criminalized the crimes. Their very nature is important to determine how a given international crime shall be universally opposable and achieves the status of jus cogens. Having 'pure' international crimes' characterization will provide sufficient legal basis for international tribunals to exercise their jurisdiction and also for states to exercise universal criminal jurisdictions.

Most of crimes are municipal crimes but only few of them are singled out as international crimes. Unfortunately, there is no single, comprehensive, universally accepted definition of international crimes. ${ }^{46}$ There is legal approach which identifies criteria of international crimes based on actual practices of international criminal law which also known as descriptive account. ${ }^{47}$ Alternatively, there is philosophical approach that refers to normative account that is questioning whether or not some crimes are appropriate or morally required to subject them to international criminalization. ${ }^{48}$ In reality, those two approaches are difficult to use

42 Maurizio Ragazzi, Op.cit., p. 446.

43 M. Cherif Bassiouni, "International Crimes: Jus Cogens and Obligatio Erga Omnes", Law and Contemporary Problems, Vol. 59, No. 4, 1966, p. 63.

44 Ulf Linderfalk, Op.cit., p. 19.

45 Ibid.

46 Bassiouni mentions that there is a significant divergence on the positions of publicists and penalist in this regard. The main divisions concern how a given international crimes achieve the status of ius cogens and the manner in which such crimes satisfy the requirements of 'the principles of legality'. See M. Cherif Basssiouni, "International Crimes...", Op.cit., pp. 63-65.

47 Win-chiat Lee, "International Crimes and Universal Jurisdiction" in Larry May and Zacharu Hiskins (eds), International Criminal Law and Philosophy, United Kingdom: Cambridge University Press, 2010, p. 15. Ibid. 
separately. As will be seen, the interpretation of the actual practice of international criminal law concerning the criteria of international crimes needs a justification through normative account for subjecting these crimes to international criminal law. ${ }^{49}$

The prohibition of international crimes is therefore paramount important for the life, security and peace of international community. Para. 3 of Preamble of the 1998 Rome Statute of International Criminal Court explicitly states that war crimes, crimes against humanity, genocide and crimes of aggression are threatening to the peace, security and well being of mankind. This rule therefore has achieved the status of jus cogens and consequently not susceptible of being set aside by agreement. It can also be seen from the drafting history (travaux preparatoir) of Article 53 VCLT that recorded several states refer to serious breach such as aggression, genocide, slavery as jus cogens..$^{50}$

The breach of universal value plays a significant role to distinguish between pure international crimes and crimes that are taken into account by international law only because of their transnational dimensions. ${ }^{51}$ But it is more important to consider that the crimes are serious crimes which the state within whose national jurisdiction they fall might well not prosecute and notably they are committed systematically by or with the tacit support of state officials. Consequently, the perpetrator will not be punished and this justifies other states to intervene by claiming universal jurisdiction over such crimes as will be seen in the next section.

\section{Combating Impunity for International Crimes as Erga Omnes Obligations}

In response to the commission of international crimes, international community has made collective efforts which aim to protect fundamental values of human being namely live, security, and peace.$^{52}$ However, positive international criminal law does not contain such explicit norms as to the effect of characterizing outlawing of international crimes as jus cogens. Consequently, it is not clear whether the status of prohibition of international crimes as jus cogens places erga omnes obligations to combat impunity upon all states especially those which are governed outside treaty law. In reality, the exercise of universal jurisdiction is more inchoate than

49 Win-chiat Lee calls his approach as interpretative and he refers to Ronald Dworkin approach in his book Law's Empire. On Dworkin's view, interpretative approach involves an interplay between consistency with facts about the practice and justification for it. See Ibid., footnote 1.

50 During the negotiations, various examples were referred to as reflecting rules of jus cogens character such as the prohibition of slave trade, prohibition of slavery, prohibition of genocide, the protection of fundamental rights, prohibition of forced labor, etc. See Oliver Dorr, Op.cit., p. 905.

51 Win-chiat Lee, Op.cit., p. 16.

52 Preamble of the Rome Statute of the Establishment of International Criminal Court (Rome Statute) para. 4 states that: "Affirming that the most serious crimes of concern to the international community as a whole must not go unpunished ..." 
established even when it is binding on states as a matter of positive law. ${ }^{53}$ Most states are reluctant to exercise their jurisdiction (enforce and adjudicate) extraterritorially, not only due to the difficulties in securing witness, testimony or corroborating evidence, ${ }^{54}$ but they just clearly do not think that the obligations really bind them. ${ }^{55}$ A good example is penal provision regarding grave breaches under the Geneva Conventions 1949. ${ }^{56}$

International law imposes state the duty to prosecute or extradite that represents the customary international law (not just treaty law) since "deeds were what counted, not just words". ${ }^{57}$ Crime is an evil, whenever it is committed, all decent folk should concern with its repression. The expression aut dedere aut judicare is modern adaptation of a phrase used by Grotius: aut dedere aut punier (extradite or punish). ${ }^{59}$ Grotius treated the duty to extradite or punish as nonbilateral obligations that owe to all states, to international community as a whole as civitas maxima since it reflects the existence of a common social or moral order which the criminal law of every state aims to secure. ${ }^{60}$

In exercising this duty, international law envisages that the primary method of judicial enforcement is the domestic court where the international crimes occurred or the national court of the state responsible for the crimes. However, given that the nature of pure inter-national crimes which are often committed by state agents as part of state policy, the government is often reluctant to prosecute their own officials engaged in such action.

Exercising universal criminal jurisdiction is one of the possible legal means to combat impunity although it is the most controversial applicability of criminal jurisdiction. This is due to the fact that it may be exercised by a state without any link to the crimes or any other connection to the state exercising such jurisdiction. ${ }^{61}$ The

53 Dalila Hoover, "Universal Jurisdiction Not So Universal: Time to Delegate to the International Criminal Court", 8 Eyes on the ICC 73 2011-2012, pp. 88-97.

54 Guy S Goodwin-Gill, “Crime in International Law: Obigations Erga Omnes and The Duty to Prosecute”, in Guy S Goodwin-Gill and Stefan Talmon (eds), The Reality of International Law, Oxford: Oxford University Press, 1999, p. 205.

55 ICJ in South West Africa Decision remarked that none has believed it had the 'standing', the legal (or to anticipate another argument, the practical) interest, to object to the apparent treaty violation. See South West Africa Cases (Ethiopia v South Africa) (Liver v South Africa) (Second Phase, 1966, I.C.J 4 (July 18). See also Alfred P Rubin, "Actio Popularis, Jus cogens and Offenses Erga Omnes?", 35 New English Law Review 265, 2000-2001, p. 268 footnote 10.

56 Article 49 Geneva Conventions.

57 M. Cherif Bassiouni and Edward M. Wise, Aut Dedere Aut Judicare...., Op.cit., p. 52.

58 Bruno Simma, "International Human Rights and general International Law: A Comparative Analysis", Collected Courses of the Academy of European Law 1993, 1995.

59 Ibid, p. 4.

60 This expression is popularized by Christian Wolff in the $18^{\text {th }}$ century as a supreme state or body politic. This also often translated as 'supreme state' that underlies assertions about common interest in repressing crimes wherever it occurs (and also assertions about the existence of genuine body of international criminal law). Ibid. p. 29.

61 Principle 1 of The Princeton Principle, available at https://lapa.princeton.edu/hosteddocs/unive jur.pdf. 
legal basis of universal jurisdiction is solely that the crimes are regarded as particularly offensive to the international community as a whole. ${ }^{62}$ The rationale of this principle is rooted from the Roman concept of actio popularis which the state acts on behalf of the international community because it has an interest in the preservation of world order as a member of that community. ${ }^{63}$

In line with the actio popularis rationale, Ago does not believe that, in the case of serious breach that calls 'crime', all states have the legitimacy to intervene the guilty state. ${ }^{64}$ Instead, the possible bearer of a right of reaction to this serious breach is the international community. ${ }^{65}$ Therefore, the distinction between 'pure' international crimes and other classes of international crimes is the way state exercising its jurisdiction both prescription and enforcement. ${ }^{66}$ The crimes against state are subject to exclusive territorial and national jurisdictions of states whilst crimes against international community as a whole subject to universal jurisdiction. To this end, it suffices to say that erga omnes conception plays important role in establishing the rights for all states or other legal entities to exercise their obligation to prosecute or extradite toward the offenders.

The Court in Barcelona Traction Case, instead of making further observation with respect to 'international community as a whole' as a separate legal entity or by making further formal test of recognition and acceptance by the community as a whole as required from peremptory norm under Article 53 VCLT, rather took a realistic approach as has been taken by its preceding advisory opinion in Genocide Convention that 'the Convention based on underlying principles that binding on all states, irrespective any convention obligation'. ${ }^{67}$ This is due to the fact that no state will recognize such heinous crimes and will claim special exemptions from such moral absolutes norms.

In practice, there have been wide states or other entities practice which acted on behalf of international community as whole to put forward claim against the

62 Malcolm Shaw, Op.cit., p. 668.

63 M. Cherif Bassiouni, "Universal Jurisdiction for International Crimes: Historical Perspectives and Contemporary Practice", 42 Virginia Journal of International Law 81, 2001, p. 8.

64 Roberto Ago, "Obligation Erga Omnes and the International Community" in J. Weiler, M. Spiedi, and A. Cessese, International Crimes of State: A Critical Analysis of the ILC's Draf Article 19 on State Responsibility, Berlin: Walter de Gruyter, 1989, p. 238.

65 Ibid.

66 Harvard Research in International Law, "Draft Conventions on Piracy with Comments", 26 American Journal of International Law 749, 758 (1932). What is then the distinction between piracy being an international crime and being a class of acts over which under international law any or all national court may claim criminal jurisdiction? The former is that the state prosecutes the foreign pirates by its own law that is made pursuant to international law. As for the later, the state prosecutes the person pursuant to the law of nations, because it believes it prosecutes the crimes based on the law of nations. The difference is conceptualization, but either way the prosecution may proceed in the national court. Kenneth S Gallant, "Jurisdiction to Adjudicate and Jurisdiction to Prescribe in International Criminal Court", 48 Vill.L.Rev 763, 2003, pp. 774-775.

67 ICJ, "Reservations to the Convention on the Prevention and Punishment of the Crime of Genocide", Advisory Opinion, ICJ Reports, 1951, p. 23. 
guilty state in the case of international crimes. Iraqi invasion against Kuwait was followed by unprecedented involvement of the international community in the procedure of processing compensation claims against aggressor state. The United Nations Claim Commission was created as a subsidiary body of UN Security Council and replacing the usual arbitral tribunal and mixed claim commission procedures. ${ }^{68}$ UN Security Council functioned reparation mechanism as a peace treaty between Iraq and international community. This illustrated the existing of inter-national community to put pressure to the observance of jus cogens rules in the form of prohibition of aggression on the basis of common interest.

In the same period, UN Security Council also established two Ad-Hoc Criminal Tribunals for Rwanda and Yugoslavia. Judges in ICTY in several cases held that the conduct of the accused as an attack of humanity itself, or as a crime against all of humankind whose harm being felt not only by the group targeted for destruction, but by all of humanity. ${ }^{69}$ ILC was also able to bring its project on State Responsibility to a close and developed new concept of fundamental norm that are now reflected in Article 26, 40 and 41 of Article on Responsibility of States for International Wrongful Act (ARSIWA).

In conclusion, erga omnes obligations to combat impunity for international crimes, shall be seen as obligations that are legally binding on all States. Erga omnes character of those obligations renders superior status as obligations that are universal and non-derogable. As moral absolute norms, these obligations thus prevail when they are in conflict with other norms such as customary international law or general principle of law. This includes the law of state immunity and immunity of state officials diplomatic that, unfortunately until present, still continue to apply and become major hurdles in the enforcement of international crimes. ${ }^{70}$

68 Stefan Kadelbach, "Jus Cogens, Obligations Erga Omnes and other Rules-The Identification of Fundamental Norms", in Christian Tomuschat and Jean-Marc Thouvenin (eds), The Fundamental Rules of the International Legal Order: Jus Cogens and Obligation Erga Omnes, The Netherlands: Martinus Nijhoff Oublishers, 2006 , p. 23.

69 See Plavsic Judgment (IT-39\&40/1-S), International Criminal Tribunal for the former Yugoslavia (ICTY) Trial Chamber 27 February 2003, para. 122 and Decision on the Defense Interlocutory Appeal on Jurisdiction, Tadic (IT-94-1-1-AR72) ICTY Appeals Chamber, 2 October 1995, para. 97. See also Luigi D. Corias, "Judging in the name of Humanity", Journal of International Criminal Justice 13, 2015, pp. 97-112.

70 State Immunity from foreign jurisdiction and Immunity (Personal or Functional) of State Official from foreign jurisdiction are two different legal theories. Both of theories may appear to have the same legal consequences namely an exclusion of responsibility, however the former entails to the state as entity and hence the type of responsibility is state responsibility. On the other hand, the later entails state officials (individual person) hinder subject of international law (state of state official) from responsibility before national court. However, the former is the principle that may hamper the foreign victim to claim for responsibility of guilty state before the victim's national court. The latter explains about the state officials that cannot be brought before foreign national court due to their personal immunity as head of state/government. For discussion regarding state immunity, see Lee M. Caplan, "State Immunity, Human Right, and Jus Cogens: A Critique of the Normative Hierarchy Theory", The American Journal of International Law, Vol. 97, pp. 741-781. See also Al-Adsani v. United Kingdom, App. No. 35763/97, ECtHR, 34 Eur. H. R. Rep. 11 (2001). As reference to Immunity of State Officials see Case Concerning Arrest Warrant of 11 April 2000 (DRC v Belgium), Judgment 14 Feb 2002, p. 3. 


\section{E. Conclusion}

International law today still sees itself as a law between states and conceives itself to be the systematic reconciling of national interest. International legal order seemed to lack any law-creating technique beyond treaties ${ }^{71}$ and thus it systematically neglects the highest interest of humanity as a whole and the interest of each human being. This can be seen from how it responded to the commission of international crimes. Suffice it to say that jus cogens rule of the outlawing of international crimes, is rule that reflects the notions that all municipal orders, with different constitutional structure and international legal order are agreed upon. However, in practice, the limitation of international law itself that is heavily rely on consent has become major hurdle in achieving global justice. The problem of translating moral imperatives regarding what later were called 'human rights' to rules of enforceable law in the international legal order seemed nearly insuperable.

ICJ has taken step towards a more progressive interpretation of fundamental value or highest interest of humanity when formally recognizing the existence of obligations erga omnes in Barcelona Traction case. Although the implications of such recognition for the purpose of standing were not addressed by the Court, erga omnes obligations can be read as the legal consequences of the breach of jus cogens in the form of establishing rights toward all states to put forward a claim against guilty state. These two conceptions can only be accepted through natural-moralist rationale and not the result of voluntarist source of law.

\section{References}

\section{Books}

Bassiouni, M. Cherif and Edward M. Wise, Aut Dedere Aut Judicare: The Duty to Extradite or Prosecute in International Law, Kluwer Academic Publishers, The Netherlands, 1995.

Boas, Gideon, William Schabas, Michael P Scharf (eds), International Criminal Justice: Legitimacy and Coherence, Edward Elgar Publishing Limited, United Kingdom, 2012.

Cassese, Antonio, and Marina Spinedi (eds), International Crimes of Sates: A Critical Analysis of the ILC's Draft Article 19 on State Responsibility, Walter de Gruyter \& Co, Berlin, 1989.

Currie , J. H. (et.al), International Law: Doctrine, Practice and Theory, Irwin Law, Toronto, 2007.

de Hoogh, Andre, Obligation Erga Omnes and International Crimes, Kluwer Law International, The Netherlands, 1996.

$71 \quad$ Alfred P. Rubin, Op.cit., p. 266. 
Why We Need Erga Omnes Character to Combat Impunity for International Crimes 376

Dinstein, Yoram (ed), International Law at a Time of Perplexity: Essay in Honour of Shabtai Rosenne, Nijhoff, Dordrecht, 1989.

Glare, P. G. W., Oxford Latin Dictionary, Oxford, 1982.

Goodwin-Gill, Guy S, and Stefan Talmon, The Reality of International Law, Oxford University Press, Oxford, 1999.

Hannikanen, L., Peremptory Norms (Jus Cogens) in International Law: Historical,

Development, Criteria, Present Status, Lakimiesliiton Kustanus Finish Lawyers' Publishing Company, Helsinki, 1988.

May, Larry and Zacharu Hiskins (eds), International Criminal Law and Philosophy, Cambridge University Press, United Kingdom, 2010.

Ragazzi, Maurizio, The Concept of International Obligations Erga Omnes, Oxford Monograph in International Law, Clarendon Press, Oxford, 1997.

Scharf, Michael P., Customary International Law in Times of Fundamental Change: Recognizing Grotian Moments, Cambridge University Press, Cambridge, 2013.

Shaw, Malcolm, International Law, $6^{\text {th }}$ Edition, Cambridge University Press, New York, 2008.

Tams, Christian J., Enforcing Obligations Erga Omnes in International Law, Cambridge University Press, United Kingdom, 2005.

Tomuschat, Christian, and Jean-Marc Thouvenin (eds), The Fundamental Rules of the International Legal Order: Jus Cogens and Obligation Erga Omnes, Martinus Nijhoff Oublishers, The Netherlands, 2006.

Vohrah, Lal Chand (et.al) (eds), International Humanitarian Series: Man's Inhumanity to Man: Essays on International Law in Honour of Antonio Cassese, Kluwer International Law, The Netherlands, 2003.

Weiler, J., M. Spiedi, and A. Cessese, International Crimes of State: A Critical Analysis of the ILC's Draf Article 19 on State Responsibility, Walter de Gruyter, Berlin, 1989.

\section{Other Documents}

Ago, Roberto, "Second Report of State Responsibility", Yearbook of International Law Commission, 20 April 1970.

Annacker, C., "The Legal Regime of Erga Omnes Obligations in International Law", 46 Austrian Journal of Public and International Law, 1994.

Bassiouni, M. Cherif, "International Crimes: Jus Cogens and Obligatio Erga Omnes", Law and Contemporary Problems, Vol. 59, No. 4, 1966. "Universal Jurisdiction for International Crimes: Historical Perspectives and Contemporary Practice", 42 Virginia Journal of International Law 81, 2001. 
Byers, Michael, "Conceptualizing the Relationship between Jus cogens and Erga Omnes Rule", Nordic Journal International Law 66: 211-239, Kluwer Law International, Netherlands, 1997.

Caplan, Lee M., "State Immunity, Human Right, and Jus Cogens: A Critique of the Normative Hierarchy Theory", The American Journal of International Law, Vol. 97.

Corias, Luigi D., "Judging in the name of Humanity", Journal of International Criminal Justice 13, 2015.

de Wet, Erika, "The Emerging International Constitutional Order: The Implications of Hierarchy in International Law for the Coherence and Legitimacy of International Decision Making", Potchefstroom Electronic Law Journal 2, 2007.

Dubois, D., "The Authority of Peremptory Norms in International Law: Sate Consent or Natural Law?", Nordic JIL 78, 2009.

Gallant, Kenneth S., "Jurisdiction to Adjudicate and Jurisdiction to Prescribe in International Criminal Court", 48 Vill.L.Rev 763, 2003.

Hoover, Dalila, "Universal Jurisdiction Not So Universal: Time to Delegate to the International Criminal Court", 8Eyes on the ICC 73 2011-2012.

International Law Commission, Reports of the Study Group on Fragmentation of International Law; "Difficulties arising from the diversification and expansion of international Law, A/CN.4/L.682", 13 April 2006. , Yearbook of ILC, 2001, Vol. II, Part Two.

Linderfalk, Ulf, "International Legal Hierarchy Revisited-The Status of Obligations Erga Omnes", 80 Nordic J.International L.1, 24, 2011.

Meron, Theodor, "On A Hierarchy of International Human Rights", 80 American Journal of International Law 1, January 1986.

Rubin, Alfred P., "Actio Popularis, Jus cogens and Offenses Erga Omnes?", 35 New English Law Review 265, 2000-2001.

Shelton, D., "Normative Hierarchy in International Law", 100 American Journal of International Law, 291, 2006.

Simma, Bruno, "International Human Rights and general International Law: A Comparative Analysis", Collected Courses of the Academy of European Law 1993, 1995.

"The Contribution of Alfred Verdross to the Theory of Law", European Journal of International Law 6, 1995.

Verdross, Alfred, "Jus Dispositivum and Jus Cogens In International Law", The American Journal of International Law, Vol. 60, 1966.

\section{Legal Documents}

Geneva Conventions.

Vienna Convention of the Law of Treaties. 
Rome Statute of the Establishment of International Criminal Court.

The Princeton Principle.

Barcelona Traction Case.

European Court of Human Rights, Al-Adsani v. United Kingdom, App. No. 35763/97, ECtHR, 34 Eur. H. R. Rep. 11 (2001).

International Court of Justice, Advisory Opinion on Reservation to the Convention on the Prevention and Punishment Crime of Genocide, ICJ Report May $28^{\text {th }}$, 1951.

, South West Africa Cases (Ethiopia v South Africa)

(Liver v South Africa) (Second Phase, 1966, I.C.J 4 (July 18). Immunity of State Officials see Case Concerning Arrest Warrant of 11 April 2000 (Democratic Republic of Congo v Belgium), Judgment 14 Feb 2002.

Questions relating to the Obligation to Prosecute or Extradite (Belgium v Senegal) 2012, ICJ Rep, (Habré decision).

International Criminal Tribunal for the former Yugoslavia, Decision on the Defense Interlocutory Appeal on Jurisdiction, Tadic (IT-94-1-1-AR72), ICTY Appeals Chamber, 2 October 1995.

39\&40/1-S), Trial Chamber 27 February 2003.

Plavsic Judgment (IT-

Harvard Research in International Law, "Draft Conventions on Piracy with Comments", 26 American Journal of International Law 749, 758 (1932) 